\title{
Architecture and Entrepreneurship
}

\section{Ivan Shumkov}

Recibido 2019.09.23 ::: Aceptado 2019.09.26 DOI: 10.5821/palimpsesto.20.8950

Persona de contacto: ivan@buildacademy.com

ORCID: https://orcid.org/0000-0001-8743-5741

Doctor Arquitecto por la Universitat Politècnica de Catalunya (UPC)

$n$ this phase of my life, I'm a New York based entrepreneur, architect, educator and the Founder of Build Academy. Below is a snapshot of a bit of my journey and my work that hopefully can be of inspiration to others. Looking back at my journey, I try to connect the dots, see how I got here and where l'm heading. Architecture has the unique capacity to manifest new realities and raise people's consciousness. It opens so many paths that can make a positive difference ve difference in the world if followed thoroughly with passion and perseverance.

\section{Education}

My passion for architecture led me to live and study in Sofia, Florence, Munich, Barcelona, Zurich, Paris, Boston and New York. For me, studying while earning scholarships was a way to meet extraordinary people, earn new knowledge and skills, and live in beautiful cities. I acquired some of the highest education in architecture, graduating at the age of 29 with 4 masters' degrees and a PhD, from some of the world's top universities such as ETSA Barcelona, University of Florence, Harvard University GSD, Columbia GSAPP, and the Polytechnic of Catalonia. I took every opportunity that I had to go further and beyond the traditional academic path. I started and led student and professional organizations, did exhibits, organized conferences, which planted the seeds and prepared me for what my work would became out into the "real world" outside of Academia.

\section{Catedra Blanca}

At ETSA Barcelona, I was involved with the Catedra Blanca for four years: first as a student (2002-03), later as a teaching assistant (2003-05) and assistant professor (2005-06) with Prof. Carlos Ferrater and Alberto Peñin. I was inspired to see how my professors and colleagues could expand the limits of our profession by being simultaneously architects, educators, researchers and leaders. This experience had a big impact on my career and helped me refine my goals and vision, preparing me for my next chapter of my life at Harvard GSD in the USA.

Architecture

In Barcelona, I worked as an intern at multiple offices, including Estudio Ferrater (later OAB). I also worked on my own projects on a number of architectural commissions and competitions. Afterwards, I continued to pursue my passion for Architecture in parallel with other professional projects. I have practiced taught, lectured, researched, exhibited and published Architecture in Europe, Brazil, Colombia, China, and the US. I became a licensed Architect in Spain and Italy and have maintained an architectural practice in New York. My design work allowed me to go deeper into my understanding of architecture as a discipline and profession I enioyed the process of meterializing and profession. I njoyed the process of materializing a vision into something physical that can have such a

\section{Research}

After graduating from ETSA Barcelona, I started my $\mathrm{PhD}$ research on the work of Le Corbusier with thesis director Prof. Josep Quetglas at the Polytechnic University of Catalonia. I won a fellowship of the Foundation Le Corbusier, which led me to Paris to live "in residence" at the home of Le Corbusier, while researching his archives. Later in 2006, I came to the USA as a Fulbright scholar to do a Masters in Architecture II at Harvard University GSD. Afterwards, I came to New York to complete his PhD at Columbia GSAPP with Prof. Kenneth Frampton, Mary McLeod and Jean Louis Cohen. In 2010, I defended my thesis "Architecture and Revolution: Pavillon des Temps Nouveaux by Le Corbusier and Pierre Jeanneret at the 1937 International Exposition in Paris." My research gave me a chance to go deep into the work and ideas of Le Corbusier and garner inspiration from his project for the "Radiant City" for my vision for the future of cities.

\section{Teaching}

started my teaching career in 2005 at the Catedra Blanca as an Assistant Professor. Later, I taught at Harvard University, Parsons School of Design, Pratt Institute, and currently I am an Adjunct Associate Professor at New York University. For me, teaching is a way of learning and sharing my skills and knowledge with others. As curator and researcher, I have completed 7 exhibits on Architecture, Art and Design and have written 3 books.

\section{Online Education}

Capitalizing on today's digital age, I chose to build a tech-based platform to create more impact and positive change. My vision was to create tech-enabled companies that would have exponential growth and positive impact on society. In 2013, I decided to expand from the traditional teaching model of universities into online education. I then created his Contemporary Architecture MOOC (Massive Open Online Courses), which has thus far attracted more than 40,000 participants since its first edition.

Entrepreneurshio

This experience led me to create Build Academy - one of the first organizations specializing in online education and professional solutions for the built environment. So far, more than 80,000 people have participated in our online courses and innovation challenges, including architects, engineers, designers, and real estate developers. Build Academy also teaches online courses in the architectural space with the intent of providing open access to skills and knowledge to anyone anywhere around the world. In addition to education, their community has expanded into a crowd-sourcing platform for providing innovative solutions to some of the world's most urgent problems within the built environment such as building emergency shelters, resilient homes, schools, infrastructure, technology, and establishing prototypes for smart cities. Build Academy became a platform that bridges academia the private and public sectors, NGOs, global experts and professionals with th environment for our cities and communities.

\section{Social Impact}

As the founder of Build Academy, I am best known for social impact work on rebuilding communities and cities destroyed by natural disasters. I have cultivated an international membership of 20,000+ professionals, working together on 7 global design challenges, and creating a platform for open source design. Together with my team, I also developed 30+ online courses and programs to educate and empower the global creative community with skills and knowledge to build better. Our work has been widely published and featured at conferences and exhibitions in the USA, Switzerland, Kenya, the Philippines and the United Nations in NY.

\section{Community}

The goal of Build Academy is to build a globa ecosystem of organizations and professionals within the building industry who work collaboratively and share their skills, knowledge and project through an open their skills, knowledge and project through an open source platform. To date, we have collaborated with on multiple impact projects. We crowd-source designs for sustainable buildings, solar lights, affordable housing and other functional resources focused on improving the human condition in underdeveloped areas. Our work is to cultivate a global impact community of professionals and companies who seek to build more professionals and companies who seck to build more the prototype for the future cities.

\section{Journeymar}

I have a deep-seated passion for travel and adventure. Exploring cultures and immersing myself in their languages has always intrigued him. So far, I have lived in 7 countries, worked across 5 continents, and speak 9 languages. I enjoy connecting with people from all over the world, which I feel evolves me as a person and allows me to share his passion, skills and knowledge with others.

\section{Looking Forward}

My life and work maintain a bridge between architecture entrepreneurship, research, teaching, leadership and social activism. I demonstrate the non-traditional path of an architect and highlight the potential within the realm of architecture. The impact of my work can be seen from the social impact projects that I was involved with, to the thousands of people that he has educated and inspired inspired through my teaching in universities and online. My work as entrepreneur went beyond into starting a global movement for resilient, sustainable, inclusive and conscious communities and cities. I am willing to collaborate with anyone who shares the same passion for discovering the world and making a positive difference into it.

VAN SHUMKOV es Doctor Arquitecto y Profesor Adjunto de la New York University. Ha sido profesor del Departamento de Proyectos Arquitectónicos de la del Departamento de Proyectos Arquitectónicos de la 